\title{
PERENCANAAN STUKTUR ATAS JEMBATAN KOMPOSIT DESA BOJONGLOA KEC.PAGELARAN KAB.CIANJUR
}

\author{
${ }^{1}$ Salman Alfarisi, ${ }^{2}$ Tanjung Rahayu \\ Program Studi Teknik Sipil Fakultas Teknik Universitas Suryakancana \\ Salman.alfa@gmail.com ${ }^{1}$, tanjungrahayu@yahoo.com²
}

\begin{abstract}
Abstrak
Jembatan adalah suatu konstruksi yang gunanya untuk meneruskan jalan melalui suatu rintangan yang berada lebih rendah. Rintangan ini biasanya jalan lain (jalan air atau jalan lalu lintas biasa). Adapun maksud dan tujuan dari proyek pembangunan Jembatan Desa Bojongloa Kecamatan Pagelaran Kabupaten Cianjur ini adalah sebagai jalan akses yang menghubungkan Desa Bojongloa dan Desa Kartaraharja untuk mempermudah akses bagi masyarakat.

Dilakukan pergantian karena jembatan sebelumnya yang mengalami kerusakan pada pelat lantai menyebabkan tidak aman bagi masyarakat untuk melalui jembatan tersebut, dan sangat berbahaya bila diabaikan terlalu lama karena semakin lama lubangnya semakin membesar.

Perencanaan ini berpedoman kepada RSNI-T 02-2005 tentang standar pembebanan untuk jembatan. Jembatan ini direncanakan dengan bentuk struktur komposit dengan panjang bentang 40 meter dengan pembagi pilar di tengah 20 meter dan lebar total 9 meter. Dalam perencanaan ini dimensi profil IWF yang digunakan adalah 800.300.16.30, dimensi profil diafragma IWF 175.175.7,5.11. Penghubung geser menggunakan paku stud diameter $16 \mathrm{~mm} 60$ buah dengan jarak $170 \mathrm{~mm}$ dan 30 buah dengan jarak $340 \mathrm{~mm}$. Penulangan pada trotoar $\emptyset 12-150 \mathrm{~mm}$ dan tulangan bagi $\emptyset 10-200 \mathrm{~mm}$, tulangan pokok pada lantai kendaraan Ø16-90 mm dan tulangan bagi $\emptyset 14-130 \mathrm{~mm}$ untuk momen negatif, dan tulangan pokok pada lantai kendaraan $\emptyset 16-130 \mathrm{~mm}$ dan tulangan bagi Ø14-190 mm untuk momen positif, tebal pelat lantai 200 mm.
\end{abstract}

Kata kunci: Jembatan, Komposit, Beton, Baja

\section{PENDAhUluan}

Pembangunan sarana transportasi sangat penting sebagai salah satu sarana transportasi menghubungkan wilayah satu dengan wilayah yang lainnya dengan tujuan untuk meningkatkan kesejahteraan masyarakat. Dengan perkembangan penduduk pada saat ini maka dibutuhkan penambahan infrastruktur jalan ataupun peremajaan infrastruktur yang sudah ada demi menunjang lancarnya mobilitas warga dan secara tidak langsung akan berdampak pada pengembangan wilayah karena usia jembatan yang sudah terbilang lama dan juga terdapat struktur jembatan yang melendut secara kasat mata.

Keberadaan jembatan saat ini terus mengalami perkembangan, dari bentuk sederhana sampai yang paling kompleks, demikian juga bahan-bahan yang digunakan mulai dari bambu, kayu, beton dan baja. Penggunaan bahan baja saat ini maupun di masa mendatang untuk struktur jembatan akan memberikan keuntungan yang berlebih terhadap perkembangan serta kelancaran sarana transportasi antar daerah maupun antar pulau yang ada diseluruh Indonesia (Siswanto, 1999).

proyek pembangunan Jembatan Desa Bojongloa Kecamatan Pagelaran Kabupaten Cianjur ini adalah sebagai jalan akses yang menghubungkan Desa Bojongloa dan Desa Kartaraharja untuk mempermudah akses bagi masyarakat, dalam mengembalikan fungsi jembatan yang seharusnya maka dilakukan pergantian jembatan sebelumnya yang mengalami kerusakan pada plat lantai menyebabkan tidak aman bagi masyarakat untuk melalui jembatan tersebut, dan sangat berbahaya bila diabaikan terlalu lama karena semakin lama lubangnya semakin membesar.

Dari latar belakang masalah yang telah diuraikan diatas, dapat dirumuskan permasalahan diatas yang timbul yaitu: Berapa dimensi struktur atas yang digunakan untuk memperoleh struktur atas jembatan kuat dan aman. 


\section{METODOLOGI PENELITIAN}

Tahap ini memberikan gambaran mengenai langkah awal sampai akhir perencanaan struktur atas jembatan. Penjelasannya dapat dituangkan dalam bentuk bagan alur sebagai berikut:

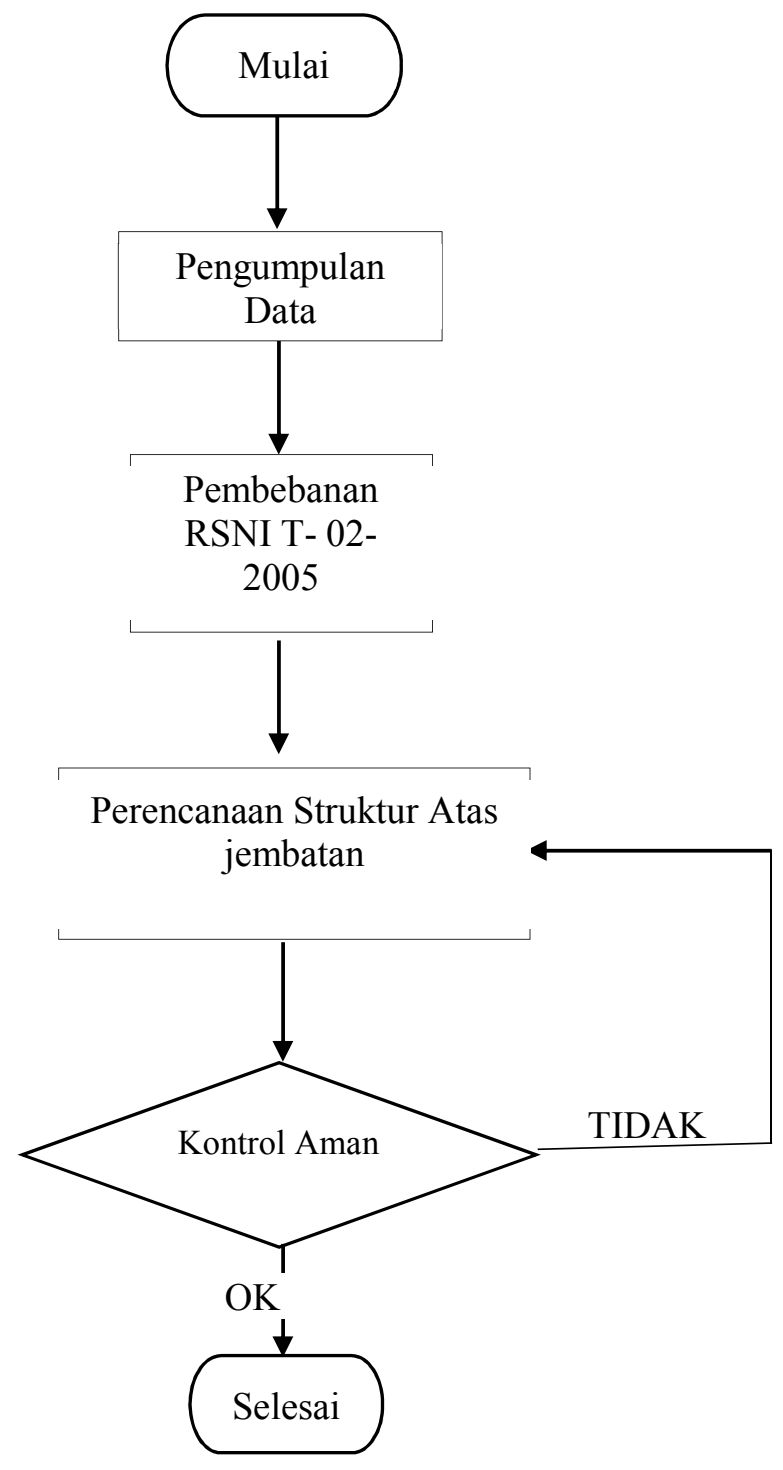

Gambar 3.1 Aliran perencanaan struktur atas

\section{a. Data}

Data yang dibutuhkan dalam pelaksanaan pekerjaan struktur atas jembatan berupa data sekunder yang diperlukan sebagai pendukung proses perencanaan. Dalam pengumpulan data, peranan instansi yang terkait sangat diperlukan untuk perencanaan jembatan Bojongloa di Cianjur.

Data sekunder yang dijadikan data perencanaan diperoleh dari instansi terkait meliputi:

1. Data Lalu Lintas Harian Rata-rata (LHR) untuk menentukan beban kendaraan terbesar yang melewati jembatan, sehingga jembatan nantinya dapat menampung kapasitas kendaraan yang melewati jalur tersebut. Data lalu lintas yang diperlukan adalah data LHR rata-rata pada ruas jalan, data ini diperoleh dari PU Bina Marga.

2. Data jembatan adalah data yang diperlukan untuk perencanaan struktur atas mengenai lokasi, bentang jembatan, lebar jembatan, mutu beton, mutu baja, dan data profil baja sehingga nanti dapat memperoleh perencanaan struktur yang kuat dan aman untuk digunakan nantinya. Data diperoleh dari instansi terkait dari PU Bina Marga, adapun data jembatan sebagai berikut.

\section{Data Jembatan}

$\begin{array}{lll}\text { Lokasi } & \begin{array}{l}\text { : Desa Bojongloa Kec. } \\ \text { Kab.Cianjur. }\end{array} & \text { Pagelaran } \\ \text { Bentang } & : 40 \mathrm{~m} \\ \text { Lebar } & : 9 \mathrm{~m} \\ \text { Mutu Beton } & : \text { K-300 } \\ \text { Mutu Baja } & : \text { BJ-50 } \\ \text { Profil Baja } & : \text { IWF } 800.300 .30 .16\end{array}$

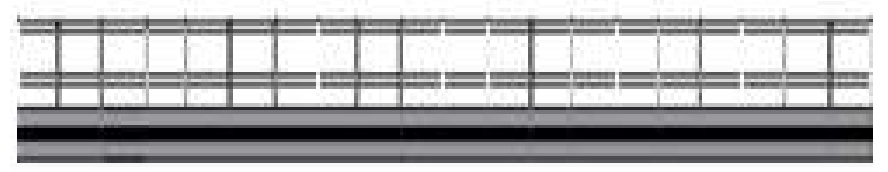

Gambar 3.2 Jembatan komposit Sumber : Dinas PU Bina Marga

Analisis data dilakukan untuk merencanakan struktur atas jembatan yang aman dan kuat. Adapun analisis data yang dilakukan meliputi:

1. Analisa data lalu-lintas

2. Analisa data jembatan

Setelah data-data yang dibutuhkan dalam perencanan struktur atas jembatan terkumpul, maka tahap analisa data dapat dilakukan dalam perencanaan berdasarkan peraturan-peraturan yang telah ditentukan.

Selanjutnya dilakukan perencanaan yang meliputi:

1. Slab sandaran dan trotoar

2. Slab lantai jembatan

3. Girder dan diafragma

\section{b. Pembebanan Struktur Atas}

Pembebanan struktur atas didasarkan pada peraturan RSNI T-02-2005 tentang pembebanan untuk struktur atas yakni jembatan. Beberapa langkah dalam menganalisa pembebanan struktur atas, antara lain yaitu:

1. Menghitung beban permanen struktur yang terdiri dari beban sendiri (MS) dan beban mati 
tambahan (MA). Perhitungan beban mati tambahan (MA) mencakup berat air hujan dan berat aspal, sedangkan perhitungan beban sendiri (MS) mencakup perhitungan berat:
a) Pelat lantai jembatan
b) Girder dan diafragma jembatan
c) Trotoar dan tiang sandaran
d) Sambungan

2. Menghitung beban lalu lintas yang terdiri dari beban lajur "D", beban pejalan kaki, dan beban gaya rem. Perhitungan beban lajur " $D$ " mencakup perhitungan Beban Terbagi Rata (BTR) dan Beban Garis Terpusat (BGT).

3. Menghitung beban dari aksi lingkungan yang terdiri dari beban angin dan beban gempa.

4. Menghitung beban aksi lainnya yang terdiri dari beban gesek pada tumpuan dan beban pelat injak.

5. Setelah menganalisa seluruh beban yang mencakup beban permanen, beban lalu lintas, beban dari aksi lingkungan dan beban dari aksi lainnya, kemudian langkah selanjutnya adalah merekap semua perhitungan ke dalam data kombinasi pembebanan yang sesuai dengan peraturan RSNI T-02-2005 tentang pembebanan jembatan.

\section{c. Perencanaan Struktur Atas jembatan}

Perencanaan struktur atas jembatan bertujuan untuk memperoleh hasil perencanaan struktur atas yang kuat dan aman ketika digunakan. Perhitungan struktur dimulai dari pembebanan dan perhitungan bangunan atas, meliputi : perhitungan pelat trotoar, perhitungan slab lantai jembatan, perhitungan girder dengan sistem komposit antara baja dan beton mutu beton dan baja yang telah direncanakan.

\section{d. Kontrol Aman}

Cek keamanan lendutan, gaya geser dan tegangan dengan beban yang telah dimasukan ke perencanaan struktur. Apabila kestabilan telah memenuhi syarat stabil maka perencanaan selesai dan apabila tidak stabil maka dihitung kembali sampai memperoleh hasil yang stabil.

\section{Pembahasan}

\section{a. Data Jembatan}

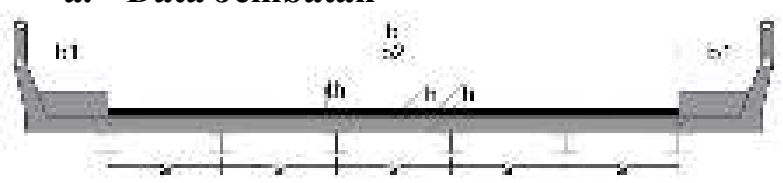

Gambar 4.1 Rencana jembatan Sumber: Pu Bina Marga
Tabel 4.1 Perencanaan jembatan

\begin{tabular}{lccc}
\hline \multicolumn{1}{c}{ Keterangan } & Simbol & $\begin{array}{c}\text { Nila } \\
\mathbf{i}\end{array}$ & Satuan \\
\hline Tebal slab lantai jembatan & $\mathrm{h}$ & 0,2 & $\mathrm{~m}$ \\
\hline Tebal lapisan aspal & $\mathrm{t}_{\mathrm{a}}$ & 0,1 & $\mathrm{~m}$ \\
\hline Tebal genangan air hujan & $\mathrm{t}_{\mathrm{h}}$ & 0,05 & $\mathrm{~m}$ \\
\hline Jarak antar girder baja & $\mathrm{s}$ & 1,4 & $\mathrm{~m}$ \\
\hline Lebar jalur lalu-lalu lintas & $\mathrm{b}_{2}$ & 7 & $\mathrm{~m}$ \\
\hline Lebar trotoar & $\mathrm{b}_{1}$ & 1 & $\mathrm{~m}$ \\
\hline Lebar total jembatan & $\mathrm{b}$ & 9 & $\mathrm{~m}$ \\
\hline Panjang bentang jembatan & $\mathrm{L}$ & 40 & $\mathrm{~m}$ \\
\hline
\end{tabular}

Sumber : PU Bina Marga

Tabel 4.2 Mutu baja yang digunakan

\begin{tabular}{lccc}
\hline \multicolumn{1}{c}{ Keterangan } & Simbol & Nilai & $\begin{array}{c}\text { Satua } \\
\text { n }\end{array}$ \\
\hline Mutu Baja & $\mathrm{Bj}$ & 50 & \\
\hline Tegangan leleh baja & $\mathrm{fy}$ & 290 & $\mathrm{MPa}$ \\
\hline Tegangan dasar Bj 41 & $\mathrm{fs}=\mathrm{fy} / 1,5$ & 193 & $\mathrm{MPa}$ \\
\hline $\begin{array}{l}\text { Tegangan putus } \\
\text { minimum }\end{array}$ & $\mathrm{Fu}$ & 500 & $\mathrm{MPa}$ \\
\hline Modulus elastis baja & $\mathrm{E}$ & $\begin{array}{c}200.00 \\
0\end{array}$ & $\mathrm{MPa}$ \\
\hline Modulus geser & $\mathrm{G}$ & $\begin{array}{c}80.000 \\
\text { Angka poisson }\end{array}$ & $\mathrm{MPa}$ \\
\hline Koefisien pemuaian & $\alpha$ & 0,3 & \\
\hline
\end{tabular}

Sumber : RSNI T-03-2005 Perencanaan struktur baja untuk jembatan

Tabel 4.3 Mutu baja tulangan

\begin{tabular}{lccc}
\hline \multicolumn{1}{c}{ Keterangan } & Simbol & Nilai & Satuan \\
\hline $\begin{array}{l}\text { Untuk baja tulangan } \\
\text { dengan } \varnothing>12 \mathrm{~mm}\end{array}$ & $\mathrm{U}$ & 39 & \\
\hline Tegangan leleh & fy & 390 & $\mathrm{MPa}$ \\
\hline $\begin{array}{l}\text { Untuk baja tulangan } \\
\text { dengan } \varnothing \leq 12 \mathrm{~mm}\end{array}$ & $\mathrm{U}$ & 24 & \\
\hline Tegangan leleh & fy & 240 & $\mathrm{MPa}$ \\
\hline
\end{tabular}

Sumber : RSNI T-03-2005 Perencanaan

Tabel 4.4 Mutu beton yang digunakan

\begin{tabular}{lccc}
\hline \multicolumn{1}{c}{ Keterangan } & Simbol & Nilai & $\begin{array}{c}\text { Satua } \\
\text { n }\end{array}$ \\
\hline $\begin{array}{l}\text { Kuat tekan } \\
\text { beton }\end{array}$ & $\mathrm{fc}^{\prime}$ & 25 & $\mathrm{MPa}$ \\
\hline $\begin{array}{l}\text { Modulus elastis } \\
\text { beton }\end{array}$ & $\mathrm{Ec}=4700 \sqrt{\mathrm{fc}^{\prime}}$ & 23.500 & $\mathrm{MPa}$ \\
\hline $\begin{array}{l}\text { Koefisien muai } \\
\text { panas }\end{array}$ & $\alpha$ & & $\mathrm{MPa}$ \\
\hline Angka poisson & $\mathrm{v}$ & 0,2 & \\
\hline
\end{tabular}




\begin{tabular}{|c|c|c|c|c|c|c|c|c|c|c|}
\hline Modulus geser & $\begin{array}{l}G \\
=\frac{E c}{[2(1+u)]}\end{array}$ & 9791,667 & $\mathrm{MPa}$ & 2 & $\begin{array}{l}\text { Beban } \\
\text { mati } \\
\text { tambahan }\end{array}$ & 2 & 0,549 & 0,196 & $\begin{array}{c}1,09 \\
8\end{array}$ & $\begin{array}{c}0,39 \\
2\end{array}$ \\
\hline \multirow{2}{*}{\multicolumn{4}{|c|}{$\begin{array}{c}\text { Sumber: RSNI T-12-2004 Perencanaan struktur } \\
\text { beton untuk jembatan }\end{array}$}} & 3 & $\begin{array}{l}\text { Beban } \\
\text { truk "T" }\end{array}$ & $\begin{array}{l}1, \\
8\end{array}$ & $\begin{array}{c}44,78 \\
9\end{array}$ & 40,31 & $\begin{array}{c}80,6 \\
2\end{array}$ & $\begin{array}{c}72,5 \\
58\end{array}$ \\
\hline & & & & 4 & $\begin{array}{l}\text { Beban } \\
\text { angin }\end{array}$ & 1 & 0,18 & 0,324 & 0,18 & $\begin{array}{c}0,32 \\
4\end{array}$ \\
\hline \multicolumn{4}{|c|}{$\begin{array}{l}\text { b. Perhitungan analisis slab lantai } \\
\text { jembatan }\end{array}$} & 5 & $\begin{array}{l}\text { Pengaruh } \\
\text { temperatu }\end{array}$ & 1 & $\begin{array}{c}0,000 \\
1\end{array}$ & 0,001 & $\begin{array}{c}0,00 \\
01\end{array}$ & $\begin{array}{c}0,00 \\
1\end{array}$ \\
\hline \multirow{2}{*}{\multicolumn{4}{|c|}{$\begin{array}{l}\text { Perhitungan analisis slab lantai jembatan } \\
\text { dengan menggunakan kombinasi tiap beban } \\
\text { dengan memperhitungkan beban-beban yang } \\
\text { bekerja pada jembatan perhitungan sebagai } \\
\text { berikut: }\end{array}$}} & 6 & $\begin{array}{l}\text { Beban } \\
\text { hidup } \\
\text { trotoar }\end{array}$ & & & & & \\
\hline & & & & & & \multicolumn{3}{|c|}{$\begin{array}{l}\text { Total momen ultimit } \\
\qquad \operatorname{slab}, \mathrm{M}_{\mathrm{u}}=\end{array}$} & $\begin{array}{c}94,4 \\
75\end{array}$ & $\begin{array}{c}73,6 \\
54\end{array}$ \\
\hline
\end{tabular}

Tabel 4.5 Beban yang bekerja

\begin{tabular}{|c|c|c|c|c|c|c|}
\hline $\mathrm{N}$ & $\begin{array}{c}\text { Jenis } \\
\text { beban }\end{array}$ & $\begin{array}{c}\text { Fakt } \\
\text { or }\end{array}$ & $\begin{array}{l}\mathrm{Da} \\
\text { ya }\end{array}$ & $\begin{array}{c}\text { Keada } \\
\text { an }\end{array}$ & $\begin{array}{c}\mathrm{M}_{\text {tump }} \\
\text { uan }\end{array}$ & $\begin{array}{c}\mathrm{M}_{\text {lapan }} \\
\text { gan }\end{array}$ \\
\hline & & beba & lay & ultimi & $(\mathrm{kNm}$ & $(\mathrm{kNm}$ \\
\hline & & $\mathrm{n}$ & an & $\mathrm{t}$ & ) & ) \\
\hline 1 & $\begin{array}{l}\text { Berat } \\
\text { sendiri }\end{array}$ & $\mathrm{Q}_{\mathrm{MS}}$ & 1 & 1,3 & 9,674 & 0,292 \\
\hline 2 & $\begin{array}{l}\text { Beban } \\
\text { mati } \\
\text { tambah } \\
\text { an }\end{array}$ & $\mathrm{Q}_{\mathrm{MA}}$ & 1 & 2 & $\begin{array}{c}0,544 \\
9\end{array}$ & 0,196 \\
\hline 3 & $\begin{array}{l}\text { Beban } \\
\text { truk } \\
\text { "T" }\end{array}$ & $\mathrm{P}_{\mathrm{TT}}$ & 1 & 1,8 & $\begin{array}{c}44,78 \\
9\end{array}$ & 40,31 \\
\hline 4 & $\begin{array}{l}\text { Beban } \\
\text { angin }\end{array}$ & $P_{E W}$ & 1 & 1,2 & 0,18 & 0,324 \\
\hline 5 & $\begin{array}{l}\text { Pengar } \\
\text { uh } \\
\text { temper } \\
\text { atur }\end{array}$ & $\Delta \mathrm{T}$ & 1 & 1,2 & $\begin{array}{c}0,000 \\
1\end{array}$ & 0,001 \\
\hline 6 & $\begin{array}{l}\text { Beban } \\
\text { hidup } \\
\text { trotoar }\end{array}$ & $\mathrm{P}_{\mathrm{TP}}$ & 1 & 1,8 & 14 & 0 \\
\hline
\end{tabular}

\section{Kombinasi 1}

Kombinasi beban yang digunakan dalam kondisi ultimit karena faktor beban ultimit merupakan faktor beban terakhir dengan nilai terbesar dibanding dengan beban layan (RSNI-02-2005 Pembebanan untuk jembatan

Tabel 4.6 Kombinasi 1

\begin{tabular}{|c|c|c|c|c|c|c|}
\hline $\mathrm{N}$ & $\begin{array}{c}\text { Jenis } \\
\text { beban }\end{array}$ & $\begin{array}{c}\mathrm{Fa} \\
\mathrm{kt} \\
\text { or } \\
\text { be } \\
\text { ba } \\
\mathrm{n}\end{array}$ & $\mathbf{M}_{\text {tump }}$ & $\begin{array}{c}\mathrm{M}_{\text {lapan }} \\
\text { gan }\end{array}$ & $\begin{array}{c}\mathrm{M}_{\mathrm{u}} \\
\text { tumpua } \\
\mathrm{n}\end{array}$ & $\begin{array}{c}\mathrm{M}_{\mathrm{u}} \\
\text { lapang } \\
\text { an }\end{array}$ \\
\hline & & & $\begin{array}{c}(\mathrm{kN} \\
\mathrm{m})\end{array}$ & $\begin{array}{c}(\mathrm{kNm} \\
)\end{array}$ & $\begin{array}{c}(\mathrm{kN} \\
\mathrm{m})\end{array}$ & $\begin{array}{c}(\mathrm{kN} \\
\mathrm{m})\end{array}$ \\
\hline 1 & $\begin{array}{l}\text { Berat } \\
\text { sendiri }\end{array}$ & $\begin{array}{l}1, \\
3\end{array}$ & 9,674 & 0,292 & $\begin{array}{c}12,5 \\
76 \\
\end{array}$ & $\begin{array}{c}0,37 \\
9\end{array}$ \\
\hline
\end{tabular}

Catatan : Untuk faktor beban angin, pengaruh temperatur, dalam kombinasi beban berlambangkan o maka nilai yang digunakan beban layan

\section{Kombinasi 2}

Tabel 4.7 Kombinasi 2

\begin{tabular}{|c|c|c|c|c|c|c|}
\hline \multirow[t]{3}{*}{ o } & $\begin{array}{l}\text { Jenis } \\
\text { beban }\end{array}$ & $\begin{array}{c}\text { Fakt } \\
\text { or }\end{array}$ & $\begin{array}{c}\mathrm{M}_{\text {tump }} \\
\text { uan }\end{array}$ & $\begin{array}{c}\mathrm{M}_{\text {lapan }} \\
\text { gan }\end{array}$ & $\begin{array}{c}\mathrm{M}_{\mathrm{u}} \\
\text { tumpua } \\
\mathrm{n}\end{array}$ & $\begin{array}{c}\mathrm{M}_{\mathrm{u}} \\
\text { lapanga } \\
\mathrm{n}\end{array}$ \\
\hline & & beba & $(\mathrm{kNm}$ & $(\mathrm{kNm}$ & $(\mathrm{kN}$ & $(\mathrm{kN}$ \\
\hline & & $\mathrm{n}$ & ) & ) & m) & $\mathrm{m})$ \\
\hline \multirow[t]{2}{*}{1} & Berat & 1,3 & 9,674 & 0,292 & 12,5 & 0,37 \\
\hline & sendiri & & & & 76 & 9 \\
\hline \multirow[t]{2}{*}{2} & Beban & 2 & 0,549 & 0,196 & 1,09 & 0,39 \\
\hline & $\begin{array}{l}\text { mati } \\
\text { tambah } \\
\text { an }\end{array}$ & & & & 8 & 2 \\
\hline \multirow[t]{2}{*}{3} & Beban & 1 & 44,78 & 40,31 & 80,6 & 72,5 \\
\hline & $\begin{array}{l}\text { truk } \\
\text { "T" }\end{array}$ & & 9 & & 2 & 58 \\
\hline 4 & $\begin{array}{l}\text { Beban } \\
\text { angin }\end{array}$ & & & & & \\
\hline \multirow[t]{2}{*}{5} & Pengar & 1 & 0,000 & 0,001 & 0,00 & 0,00 \\
\hline & $\begin{array}{l}\text { uh } \\
\text { tempera } \\
\text { tur }\end{array}$ & & 1 & & 01 & 1 \\
\hline \multirow[t]{4}{*}{6} & Beban & 1,8 & 14 & 0 & 24,7 & 0 \\
\hline & $\begin{array}{l}\text { hidup } \\
\text { trotoar }\end{array}$ & & & & 5 & \\
\hline & & $1 \mathrm{mo}$ & en ulti1 & it slab, & 83,2 & 41,0 \\
\hline & & & & $\mathrm{M}_{\mathrm{u}}=$ & 14 & 82 \\
\hline
\end{tabular}

Catatan : Untuk faktor beban truk, pengaruh temperatur, dalam kombinasi beban berlambangkan o maka nilai yang digunakan beban layan. 


\section{Kombinasi 3}

Tabel 4.8 Kombinasi 3

\begin{tabular}{|c|c|c|c|c|c|c|}
\hline $\begin{array}{l}\mathrm{N} \\
\mathrm{o}\end{array}$ & $\begin{array}{l}\text { Jenis } \\
\text { beban }\end{array}$ & $\begin{array}{l}\text { Fakt } \\
\text { or }\end{array}$ & $\mathrm{M}_{\text {tump }}$ & $\begin{array}{c}\mathrm{M}_{\text {lapan }} \\
\text { gan }\end{array}$ & $\begin{array}{c}\mathrm{M}_{\mathrm{u}} \\
\text { tumpua }\end{array}$ & $\begin{array}{c}\mathrm{M}_{\mathrm{u}} \\
\text { lapanga }\end{array}$ \\
\hline & & beba & $(\mathrm{kNm}$ & $(\mathrm{kNm}$ & $(\mathrm{kN}$ & $(\mathrm{kN}$ \\
\hline & & $\mathrm{n}$ & ) & ) & m) & m) \\
\hline 1 & $\begin{array}{l}\text { Berat } \\
\text { sendiri }\end{array}$ & 1,3 & 9,674 & 0,292 & $\begin{array}{c}12,5 \\
76\end{array}$ & $\begin{array}{c}0,37 \\
9\end{array}$ \\
\hline 2 & $\begin{array}{l}\text { Beban } \\
\text { mati } \\
\text { tambah } \\
\text { an }\end{array}$ & 2 & 0,549 & 0,196 & $\begin{array}{c}1,09 \\
8\end{array}$ & $\begin{array}{c}0,39 \\
2\end{array}$ \\
\hline 3 & $\begin{array}{l}\text { Beban } \\
\text { truk } \\
\text { "T" }\end{array}$ & 1 & $\begin{array}{c}44,78 \\
9\end{array}$ & 40,31 & $\begin{array}{c}80,6 \\
2\end{array}$ & $\begin{array}{c}72,5 \\
58\end{array}$ \\
\hline 4 & $\begin{array}{l}\text { Beban } \\
\text { angin }\end{array}$ & 1 & 0,18 & 0,324 & 0,18 & $\begin{array}{c}0,32 \\
4\end{array}$ \\
\hline 5 & $\begin{array}{l}\text { Pengar } \\
\text { uh } \\
\text { tempera } \\
\text { tur }\end{array}$ & 1 & $\begin{array}{c}0,000 \\
1\end{array}$ & 0,001 & $\begin{array}{c}0,00 \\
01\end{array}$ & $\begin{array}{c}0,00 \\
1\end{array}$ \\
\hline 6 & $\begin{array}{l}\text { Beban } \\
\text { hidup } \\
\text { trotoar }\end{array}$ & & & & & \\
\hline
\end{tabular}

Total momen ultimit slab, $\quad 58,6 \quad 41,4$

$\mathrm{M}_{\mathrm{u}}=44 \quad 06$

Catatan : Untuk faktor beban truk, pengaruh temperatur, dalam kombinasi beban berlambangkan o maka nilai yang digunakan beban layan

\section{Kombinasi 4}

Tabel 4.9 Kombinasi 4

\begin{tabular}{|c|c|c|c|c|c|c|}
\hline N & $\begin{array}{l}\text { Jenis } \\
\text { beban }\end{array}$ & $\begin{array}{l}\text { Fakt } \\
\text { or }\end{array}$ & $\begin{array}{c}\mathrm{M}_{\text {tump }} \\
\text { uan }\end{array}$ & $\begin{array}{c}\mathrm{M}_{\text {lapan }} \\
\text { gan }\end{array}$ & $\begin{array}{c}\mathrm{M}_{\mathrm{u}} \\
\text { tumpua }\end{array}$ & $\begin{array}{c}\mathrm{M}_{\mathrm{u}} \\
\text { lapang }\end{array}$ \\
\hline & & beba & $(\mathrm{kNm}$ & $(\mathrm{kNm}$ & $\frac{\mathrm{n}}{(\mathrm{kN}}$ & (kN \\
\hline & & $\mathrm{n}$ & ) & ) & m) & m) \\
\hline 1 & $\begin{array}{l}\text { Berat } \\
\text { sendiri }\end{array}$ & 1,3 & 9,674 & 0,292 & $\begin{array}{c}12,5 \\
76\end{array}$ & $\begin{array}{c}0,37 \\
9\end{array}$ \\
\hline 2 & $\begin{array}{l}\text { Beban } \\
\text { mati } \\
\text { tambah } \\
\text { an }\end{array}$ & 2 & 0,549 & 0,196 & $\begin{array}{c}1,09 \\
8\end{array}$ & $\begin{array}{c}0,39 \\
2\end{array}$ \\
\hline 3 & $\begin{array}{l}\text { Beban } \\
\text { truk "T" }\end{array}$ & 1 & $\begin{array}{c}44,78 \\
9\end{array}$ & 40,31 & $\begin{array}{c}44,7 \\
89\end{array}$ & $\begin{array}{c}40,3 \\
1\end{array}$ \\
\hline 4 & $\begin{array}{l}\text { Beban } \\
\text { angin }\end{array}$ & 1,2 & 0,18 & 0,324 & 0,21 & 0,39 \\
\hline 5 & $\begin{array}{l}\text { Pengar } \\
\text { uh } \\
\text { tempera } \\
\text { tur }\end{array}$ & 1 & $\begin{array}{c}0,000 \\
1\end{array}$ & 0,001 & $\begin{array}{c}0,00 \\
01\end{array}$ & $\begin{array}{c}0,00 \\
1\end{array}$ \\
\hline 6 & $\begin{array}{l}\text { Beban } \\
\text { hidup } \\
\text { trotoar }\end{array}$ & & & & & \\
\hline
\end{tabular}

Total momen ultimit slab, $\quad 58,6 \quad 41,4$

$\mathrm{M}_{\mathrm{u}}=8$

Catatan : Untuk faktor beban truk, pengaruh temperatur, dalam kombinasi beban berlambangkan o maka nilai yang digunakan beban layan

\section{Kombinasi 5}

Tabel 4.10 Kombinasi 5

\begin{tabular}{|c|c|c|c|c|c|c|}
\hline $\begin{array}{l}\mathrm{N} \\
\mathrm{o}\end{array}$ & $\begin{array}{c}\text { Jenis } \\
\text { beban }\end{array}$ & $\begin{array}{c}\text { Fakt } \\
\text { or }\end{array}$ & $\begin{array}{c}\mathrm{M}_{\text {tump }} \\
\text { un }\end{array}$ & $\underset{\substack{\text { lapan } \\
\text { gan }}}{\mathrm{C}_{\text {and }}}$ & $\begin{array}{c}\mathrm{M}_{\mathrm{u}} \\
\text { tumpua }\end{array}$ & $\begin{array}{c}\mathrm{M}_{\mathrm{u}} \\
\text { lapanga }\end{array}$ \\
\hline & & beba & $(\mathrm{kNm}$ & $(\mathrm{kNm}$ & $(\mathrm{kN}$ & $(\mathrm{kN}$ \\
\hline & & $\mathrm{n}$ & ) & ) & m) & m) \\
\hline 1 & $\begin{array}{l}\text { Berat } \\
\text { sendiri }\end{array}$ & 1,3 & 9,674 & 0,292 & $\begin{array}{c}12,5 \\
76\end{array}$ & $\begin{array}{c}0,37 \\
9\end{array}$ \\
\hline 2 & $\begin{array}{l}\text { Beban } \\
\text { mati } \\
\text { tambah } \\
\text { an }\end{array}$ & 2 & 0,549 & 0,196 & $\begin{array}{c}1,09 \\
8\end{array}$ & $\begin{array}{c}0,39 \\
2\end{array}$ \\
\hline 3 & $\begin{array}{l}\text { Beban } \\
\text { truk } \\
\text { "T" }\end{array}$ & 1 & $\begin{array}{c}44,78 \\
9\end{array}$ & 40,31 & $\begin{array}{c}44,7 \\
89\end{array}$ & $\begin{array}{c}40,3 \\
1\end{array}$ \\
\hline 4 & $\begin{array}{l}\text { Beban } \\
\text { angin }\end{array}$ & & & & & \\
\hline 5 & $\begin{array}{l}\text { Pengar } \\
\text { uh } \\
\text { tempera } \\
\text { tur }\end{array}$ & & & & & \\
\hline 6 & $\begin{array}{l}\text { Beban } \\
\text { hidup } \\
\text { trotoar }\end{array}$ & & & & & \\
\hline \multicolumn{5}{|c|}{ Total momen ultimit slab, } & $\begin{array}{c}58,4 \\
6 \\
\end{array}$ & $\begin{array}{c}41,0 \\
82 \\
\end{array}$ \\
\hline
\end{tabular}

Catatan : Untuk faktor beban truk, pengaruh temperatur, dalam kombinasi beban berlambangkan o maka nilai yang digunakan beban layan

\section{Kombinasi 6}

Tabel 4.11 Kombinasi 6

\begin{tabular}{ccccccc}
\hline $\begin{array}{c}\mathrm{N} \\
\mathrm{o}\end{array}$ & $\begin{array}{c}\text { Jenis } \\
\text { beban }\end{array}$ & $\begin{array}{c}\text { Fakt } \\
\text { or }\end{array}$ & $\begin{array}{c}\mathrm{M}_{\text {tum }} \\
\text { puan }\end{array}$ & $\begin{array}{c}\mathrm{M}_{\text {lapa }} \\
\text { ngan }\end{array}$ & $\begin{array}{c}\mathrm{M}_{\mathrm{u}} \\
\text { tumpu } \\
\text { an }\end{array}$ & $\begin{array}{c}\mathrm{M}_{\mathrm{u}} \\
\text { lapang } \\
\text { an }\end{array}$ \\
\hline & & $\begin{array}{c}\text { beb } \\
\text { an }\end{array}$ & $\begin{array}{c}(\mathrm{kN} \\
\mathrm{m})\end{array}$ & $\begin{array}{c}(\mathrm{kN} \\
\mathrm{m})\end{array}$ & $\begin{array}{c}(\mathrm{kN} \\
\mathrm{m})\end{array}$ & $\begin{array}{c}(\mathrm{kN} \\
\mathrm{m})\end{array}$ \\
\hline 1 & $\begin{array}{l}\text { Berat } \\
\text { sendiri }\end{array}$ & 1,3 & 9,67 & 0,29 & $\begin{array}{c}12,5 \\
7\end{array}$ & 0,37 \\
& & 4 & 2 & 76 & 9 \\
\hline 2 & $\begin{array}{l}\text { Beban } \\
\text { mati }\end{array}$ & 2 & 0,54 & 0,19 & 1,09 & 0,39 \\
& & 9 & 6 & 8 & 2 \\
& $\begin{array}{l}\text { tambah } \\
\text { an }\end{array}$ & & & & & \\
\hline 3 & $\begin{array}{l}\text { Beban } \\
\text { truk } \\
\text { "T" }\end{array}$ & & & & & \\
\hline 4 & $\begin{array}{l}\text { Beban } \\
\text { angin }\end{array}$ & 1 & 0,18 & 0,32 & 0,18 & 0,32 \\
\hline
\end{tabular}




\begin{tabular}{|c|c|c|c|c|c|c|}
\hline 5 & $\begin{array}{l}\text { Pengar } \\
\text { uh } \\
\text { temper } \\
\text { atur }\end{array}$ & 1 & $\begin{array}{c}0,00 \\
01\end{array}$ & $\begin{array}{c}0,00 \\
1\end{array}$ & $\begin{array}{c}0,00 \\
01\end{array}$ & $\begin{array}{c}0,00 \\
1\end{array}$ \\
\hline \multirow[t]{2}{*}{6} & $\begin{array}{l}\text { Beban } \\
\text { hidup } \\
\text { trotoar }\end{array}$ & & & & & \\
\hline & & Tot & $\begin{array}{r}\text { nome } \\
\text { slc }\end{array}$ & $\begin{array}{l}\mathrm{M}_{\mathrm{u}}= \\
\text { litimit }\end{array}$ & $\begin{array}{c}13,8 \\
5\end{array}$ & $\begin{array}{c}1,09 \\
5\end{array}$ \\
\hline
\end{tabular}

Catatan : Untuk faktor beban truk, pengaruh temperatur, dalam kombinasi beban berlambangkan o maka nilai yang digunakan beban layan

\section{c. Pembesian Slab}

Diambil momen yang terbesar dari perhitungan kombinasi beban karena untuk menjaga keamanan struktur dari momen terbesar yang diterima, baik momen tumpuan dan lapangan.

Untuk perhitungan pembesian slab lantai jembatan karena terdapat momen tumpuan dan lapangan.

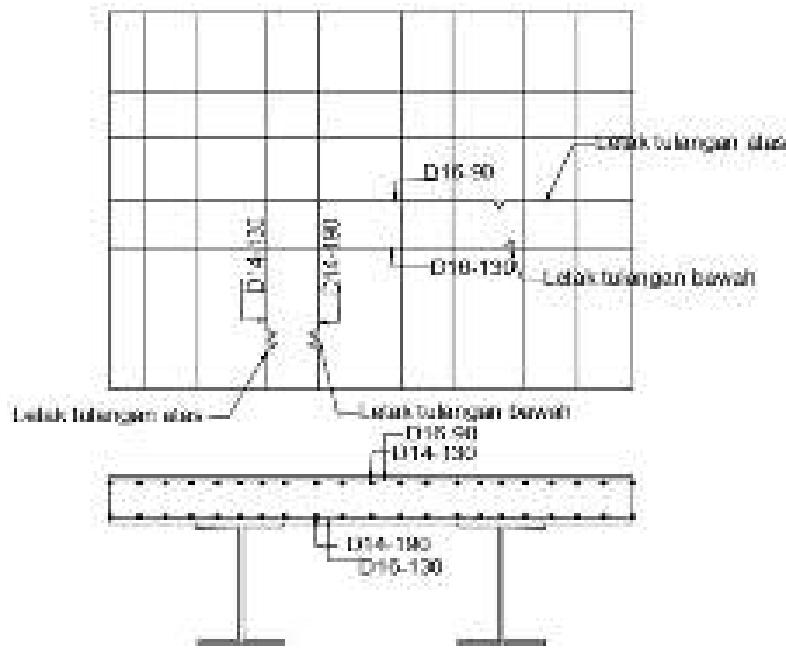

Gambar 4.1 Pembesian slab lantai kendaraan Sumber: RSNI T-12-2004 Perencanaan struktur beton untuk jembatan

\section{d. Kontrol Lendutan Slab}

Batas-batas lendutan untuk keadaan kemampuan layan batas harus sesuai dengan struktur, fungsi penggunaan, sifat pembebanan, serta elemenelemen yang didukung oleh struktur tersebut.

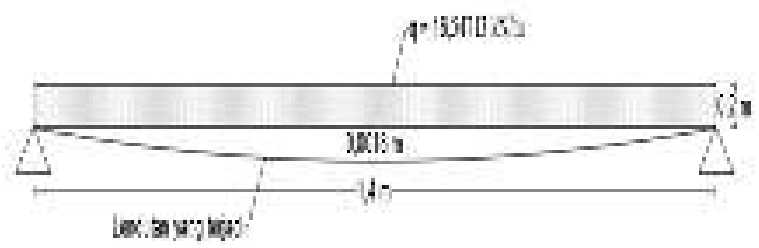

Gambar 4.2 Lendutan total yang terjadi Sumber: RSNI T-12-2004 Perencanaan struktur beton untuk jembatan

\section{e. Kontrol Tegangan Geser}

Perencanaan geser untuk komponen struktur terlentur didasarkan pada asumsi bahwa sebagian gaya geser ditahan oleh beton dan selebihnya dilimpahkan pada tulangan geser.

Tabel 4.12 Kontrol tegangan geser

\begin{tabular}{|c|c|c|}
\hline Keterangan & Nilai & Satuan \\
\hline $\begin{array}{ll}\text { Mutu beton } & \text { Kuat tekan beton, } \\
\mathrm{K}-300 & \mathrm{fc}^{\prime}=\end{array}$ & 25 & Mpa \\
\hline Kuat geser pons yang & 1,5 & Mpa \\
\hline diisyaratkan $\quad F v=0,3 \sqrt{\mathrm{fc}^{\prime}}=$ & & \\
\hline $\begin{array}{l}\text { Faktor reduksi kekuatan geser } \\
\qquad \phi=\end{array}$ & 0,7 & \\
\hline $\begin{array}{l}\text { Beban roda truk "T" pada slab } \\
\mathrm{P}_{\mathrm{TT}}=\end{array}$ & 146,25 & $\mathrm{~N}$ \\
\hline $\begin{array}{r}\text { Selimut beton } \\
\text { ts }=\end{array}$ & 40 & $\mathrm{~mm}$ \\
\hline $\begin{array}{l}\text { Jarak tulangan terhadap sisi luar } \\
\text { beton, } \mathrm{d}^{\prime}=\text { ts }-0,5 \emptyset=\end{array}$ & 32 & $\mathrm{~mm}$ \\
\hline $\begin{array}{r}\text { Tebal lapisan aspal } \\
t_{\mathrm{a}}=\end{array}$ & 100 & $\mathrm{~m}$ \\
\hline $\begin{array}{r}\text { Tebal slab lantai jembatan } \\
\mathrm{h}=\end{array}$ & 200 & $\mathrm{~m}$ \\
\hline $\begin{array}{l}\text { Lebar tampak samping ban } \\
\text { menyentuh } \text { slab } \quad \mathrm{a}=\end{array}$ & 200 & $\mathrm{~mm}$ \\
\hline Lebar tampak depan ban & 500 & $\mathrm{~mm}$ \\
\hline $\begin{array}{l}\text { Lebar tranfers beban dari tampak } \\
\text { samping ban menyentuh slab }\end{array}$ & 600 & $\mathrm{~mm}$ \\
\hline \multicolumn{3}{|l|}{$\mathrm{u}=\mathrm{a}+2 \cdot \mathrm{t}_{\mathrm{a}}+\mathrm{h}=$} \\
\hline \multirow{2}{*}{$\begin{array}{l}\text { Lebar tranfers beban dari tampak } \\
\text { depan ban menyentuh slab } \\
\qquad \mathrm{v}=\mathrm{b}+2 \cdot \mathrm{t}_{\mathrm{a}}+\mathrm{h}=\end{array}$} & 900 & $\mathrm{~mm}$ \\
\hline & \multicolumn{2}{|c|}{$\begin{array}{r}\mathrm{v}=\mathrm{b}+2 \cdot \mathrm{t}_{\mathrm{a}}+\mathrm{h}= \\
\text { Tebal efektif } s l a b\end{array}$} \\
\hline \multicolumn{3}{|l|}{$\mathrm{d}=\mathrm{h}-\mathrm{d}^{\prime}=$} \\
\hline $\begin{array}{r}\text { Luas bidang geser } \\
\mathrm{Av}=2 \cdot(\mathrm{u}+\mathrm{h}) \mathrm{d}=\end{array}$ & 268800 & $\mathrm{~mm}^{2}$ \\
\hline $\begin{array}{r}\text { Gaya geser pons nominal } \\
\text { Pn }=\mathrm{Av} . \mathrm{Fv}=\end{array}$ & 403200 & $\mathrm{~N}$ \\
\hline$\phi P n=$ & 282240 & $\mathrm{~N}$ \\
\hline \multicolumn{3}{|l|}{$\gamma_{T T}^{U}=$} \\
\hline $\begin{array}{l}\text { Beban ultimit roda truk pada slab, } \\
\mathrm{Pu}=\gamma_{\mathrm{TT}}^{\mathrm{U}} \cdot \mathrm{P}_{\mathrm{TT}}=\end{array}$ & 263250 & $\mathrm{~N}$ \\
\hline $\mathrm{Pu}<\phi \mathrm{P}$ & Aman & \\
\hline
\end{tabular}

\section{f. Girder Penampang Sebelum Komposit}

Komposit merupakan material yang tersusun atas campuran dua atau lebih material dengan sifat kimia dan fisika berbeda menghasilkan sebuah material baru yang memiliki sifat-sifat berbeda dengan material-material penyusunnya. Kondisi sebelum komposit dimana suata campuran dua material atau lebih belum menyatu. Adapun 
tahapan perencanaan struktur jembatan sebagai berikut

\section{Kondisi Girder Sebelum Komposit}

Tabel 4.13 Beban sebelum komposit

\begin{tabular}{clcc}
\hline No & \multicolumn{2}{c}{ Jenis beban } & $\begin{array}{c}\text { Beban } \\
(\mathrm{kN} / \mathrm{m})\end{array}$ \\
\hline 1 & $\begin{array}{l}\text { Berat sendiri } \\
\text { profil baja }\end{array}$ & WF & 2,41 \\
\hline 2 & $\begin{array}{l}\text { Berat } \\
\text { diafragma }\end{array}$ & $\begin{array}{l}\text { WF } \\
175.175 .7,5.11\end{array}$ \\
\hline 3 & Berat bekisting dari kayu & 0,402 \\
\hline 4 & Slab beton & $1,4.0,2.25$ & 5 \\
\hline \multicolumn{4}{c}{ Total beban mati girder sebelum } \\
& \multicolumn{3}{c}{10,312} \\
\hline
\end{tabular}

Sumber: RSNI-02-2005 Pembebanan untuk jembatan

Perancah dan bekisting berfungsi untuk mendapatkan suatu konstruksi beton yang diinginkan sesuai dengan porsinnya sebagai bangunan pembantu. Acuan perancah bersifat sementara yang harus kuat dan kokoh, namun mudah dibongkar agar tidak menimbulkan kerusakan pada beton.

Pada tahap pertama, kondisi tidak komposit karena beton belum mengeras, beban sepenuhnya dipikul girder baja.

Beban hidup sebelum komposit, merupakan beban hidup pekerja pada saat pelaksanaan konstruksi, dan diambil $\mathrm{ql}=5 \mathrm{kN} / \mathrm{m} 2$ (Beban minimum untuk perancangan bangunan gedung dan struktur lain SNI 03-1727-2013)

Beban hidup girder sebelum komposit

$\mathrm{QL}=\mathrm{s} \cdot \mathrm{ql}$

$$
=1,4.5=7 \mathrm{kN} / \mathrm{m}
$$

Total beban pada girder sebelum komposit

QMS total $=$ QMS + QL

$$
=10,312+7=17,312 \mathrm{kN} / \mathrm{m}
$$

\section{Tegangan Pada Girder Sebelum Komposit}

L : Panjang bentang jembatan (diambil jarak antar pilar ), QL : Beban hidup girder sebelum komposit QMS total : Total beban pada girder sebelum komposit, QMS : Beban mati girder sebelum komposit.

Panjang bentang girder $\mathrm{L}=20 \mathrm{~m}$

Momen tahanan $(\mathrm{Wx})=8.400 \mathrm{~cm} 3=8400000$

(Tabel profil baja IWF 800.300)

Momen maksimum akibat beban mati

$$
\begin{aligned}
\mathrm{M} & =\frac{1}{8} \mathrm{Q}_{\text {MS total }} \cdot \mathrm{L}^{2} \\
& =\frac{1}{8} 17,312 \cdot 20^{2}=865,6 \mathrm{kNm}
\end{aligned}
$$

Tegangan lentur yang terjadi

$$
\begin{aligned}
& \quad \mathrm{f}=\mathrm{M} \frac{10^{6}}{\mathrm{Wx}}=865,6 \frac{10^{6}}{8400000}=103,048 \mathrm{Mpa} \\
& \mathrm{f}<193 \\
& \mathrm{f}<193 \mathrm{MPa} \text { Aman }(\mathrm{OK})
\end{aligned}
$$

\section{Lendutan Pada Girder Sebelum Komposit}

QMS total $=17,312 \mathrm{kN} / \mathrm{m}$

$\mathrm{L}=20 \mathrm{~m}$

$\mathrm{E}=200.000 .000 \mathrm{kPa}$

$\mathrm{Ix}=0,00339 \mathrm{~m} 4$

$\frac{\mathrm{L}}{240}=\frac{20}{240}=0,08333 \mathrm{~m}$

$\boldsymbol{\delta}=\frac{5 \cdot \mathrm{Q}_{\mathrm{MS} \text { total }} \cdot \mathrm{L}^{4}}{348 \mathrm{E} \cdot \mathrm{Ix}}$

$=\frac{5 \cdot 17,312 \cdot 20^{4}}{384 \cdot(200000000 \cdot 0,00339)}=0,05 \mathrm{~m}$

$\delta<\frac{\mathrm{L}}{240}$ Aman

\section{Beban Pada Girder Komposit}

Berdasarkan perencanaan untuk jembatan dalam memperoleh perencanaan yang kuat dan aman maka diperhitungan beban yang bekerja sesuai pembebanan yang berlaku, beban-beban yang bekerja terhadap girder komposit

Dimensi girder yang digunakan adalah IWF 800.300.16.30, adapun data teknis baja sebagai berikut. Baja pada girder menggunakan baja dengan $\mathrm{BJ}-50$ dengan :

Tegangan leleh (fy) $=290 \mathrm{Mpa}$

Tegangan putus $(\mathrm{fu})=500 \mathrm{Mpa}$

Tabel 4.14 Data profil baja

\begin{tabular}{lccc}
\hline \multicolumn{1}{c}{ Profil Baja } & WF & $\mathbf{8 0 0 . 3 0 0 . 1 6 . 3 0}$ & \\
\hline Berat profil baja & $\mathrm{W}_{\text {profil }}$ & 2,41 & $\mathrm{kN} / \mathrm{m}$ \\
\hline Tinggi & $\mathrm{d}$ & 800 & $\mathrm{~mm}$ \\
\hline Lebar & $\mathrm{b}$ & 300 & $\mathrm{~mm}$ \\
\hline Tebal web & $\mathrm{t}_{\mathrm{w}}$ & 16 & $\mathrm{~mm}$ \\
\hline Tebal flange & $\mathrm{t}_{\mathrm{f}}$ & 30 & $\mathrm{~mm}$ \\
\hline Luas penampang & $\mathrm{A}$ & 30.760 & $\mathrm{~mm}^{2}$ \\
\hline Tahanan momen & $\mathrm{Z}_{\mathrm{x}}$ & 6.700 .000 & $\mathrm{~mm}^{3}$ \\
\hline Momen inersia & $\mathrm{I}_{\mathrm{x}}$ & 3.390 .000 .000 & $\mathrm{~mm}^{4}$ \\
\hline
\end{tabular}

Sumber: Tabel profil baja Kanisius 1988 
Tabel 4.15 Total beban yang bekerja berdasarkan kombinasi beban ultimit

\begin{tabular}{|c|c|c|c|c|c|c|}
\hline$N$ & $\begin{array}{c}\text { Jenis } \\
\text { Beban }\end{array}$ & $\begin{array}{c}\text { Fact } \\
\text { or } \\
\text { beba } \\
n\end{array}$ & $\begin{array}{c}M m a \\
x \\
(k N m \\
)\end{array}$ & $\begin{array}{c}V m a \\
x \\
(k N m \\
)\end{array}$ & $\begin{array}{c}\text { Mmax } \\
\text { terfakt } \\
\text { or } \\
\text { ulitmit } \\
(\mathrm{kNm})\end{array}$ & $\begin{array}{c}\text { Vmax } \\
\text { terfakt } \\
\text { or } \\
\text { ulitmit } \\
(\mathrm{kN})\end{array}$ \\
\hline 1 & $\begin{array}{l}\text { Berat } \\
\text { sendiri } \\
\text { (MS) }\end{array}$ & 1,3 & 490,6 & 98,12 & 638 & 127,56 \\
\hline 2 & $\begin{array}{l}\text { Beban } \\
\text { mati } \\
\text { tambah } \\
\text { an } \\
\text { (MA) }\end{array}$ & 2 & 188,3 & 37,66 & 376,6 & 75,32 \\
\hline 3 & $\begin{array}{l}\text { Beban } \\
\text { lajur } \\
\text { "D" } \\
\text { (TD) }\end{array}$ & 1 & $\begin{array}{c}1110, \\
2\end{array}$ & $\begin{array}{c}174,0 \\
2\end{array}$ & 1110,2 & 174,02 \\
\hline 4 & $\begin{array}{l}\text { Gaya } \\
\text { rem } \\
\text { (TB) }\end{array}$ & 1,8 & 56 & 6 & 100,89 & 10,09 \\
\hline 5 & $\begin{array}{l}\text { Beban } \\
\text { angin } \\
(\mathrm{EW})\end{array}$ & 1,2 & 50,4 & 10,08 & 60,48 & 12,10 \\
\hline 6 & $\begin{array}{l}\text { Beban } \\
\text { gempa } \\
\text { (EQ) }\end{array}$ & 1 & 67,89 & $\begin{array}{c}13,57 \\
8\end{array}$ & 67,89 & 13,58 \\
\hline & & \multicolumn{3}{|c|}{ Total beban terfaktor $=$} & 2354 & 412,66 \\
\hline
\end{tabular}

\section{Girder Penampang Setelah Komposit}

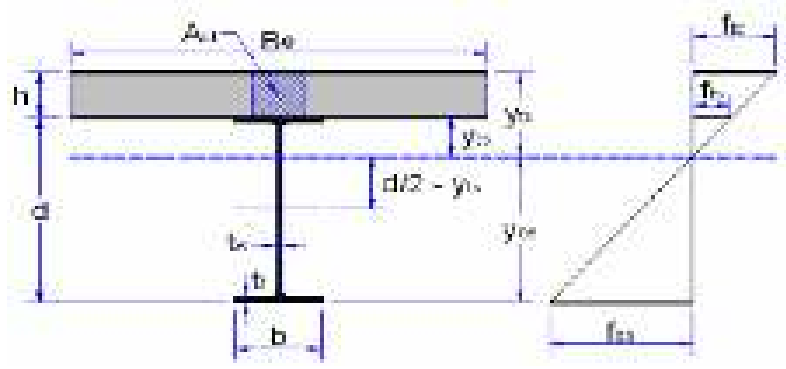

Gambar 4.3 Girder penampng setelah komposit Sumber : RSNI T-03-2005 Perencanaan struktur baja untuk jembatan

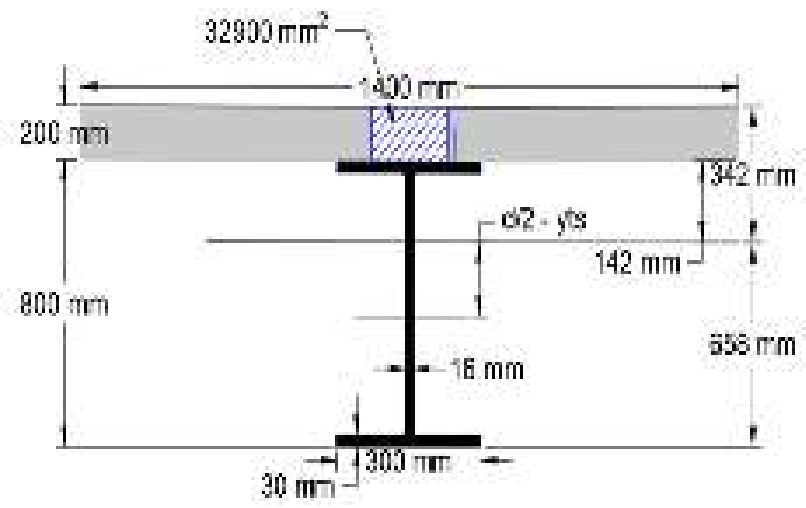

Gambar 4.4 Perhitungan girder komposit $\frac{1}{12}$ Be $\cdot \mathrm{h}^{3}=\frac{1}{12} 1400 \cdot 200^{3}=933.333 \mathrm{~mm} 4$

Act. $\left(\mathrm{ytc}-\frac{\mathrm{h}}{2}\right)^{2}=32900 \cdot\left(341,59597-\frac{200}{2}\right)^{2}$ $=1.920 .327 .495,791 \mathrm{~mm}^{4}$

$\mathrm{Ix}=3.390 .000 .000 \mathrm{~mm}^{4}$

$\mathrm{A}\left(\frac{\mathrm{d}}{2} \text {-yts }\right)^{2}=30760\left(\frac{800}{2}-141,59597\right)^{2}=2.053 .926 \cdot \mathrm{mm}^{4}$ Icom $=8.297 .587 .181,904 \mathrm{~mm}^{4}$

Tahanan momen penampang komposit :

Sisi atas beton $\mathrm{Wtc}=\mathrm{Icom} / \mathrm{ytc}$

$341,59597=24.290 .646,556 \mathrm{~mm}^{3}$

$$
=8.297 .587 .181,904 /
$$

Sisi atas baja Wts $=$ Icom $/$ yts

$141,59597=58.600 .443,754 \mathrm{~mm}^{3}$

$$
=8.297 .587 .181,904 /
$$

Sisi bawah baja $\mathrm{Wbs}=\mathrm{Icom} / \mathrm{ybs}$

$$
=8.297 .587 .181,904 /
$$

$658,40402=12.602 .576,705 \mathrm{~mm}^{3}$

\section{Tegangan Pada Girder Komposit}

Tegangan yang terjadi setelah campuran dua material beton dan baja menyatu, tahapan perhitungan tegangan yang terjadi pada girder

\begin{tabular}{|c|c|c|c|c|c|}
\hline \multirow[t]{3}{*}{$\begin{array}{l}\mathrm{N} \\
\mathrm{o}\end{array}$} & \multicolumn{2}{|c|}{$\begin{array}{l}\text { Tegangan yang } \\
\text { terjadi pada sisi }\end{array}$} & $\begin{array}{l}\text { Atas } \\
\text { Beton }\end{array}$ & $\begin{array}{l}\text { Atas } \\
\text { Baja }\end{array}$ & $\begin{array}{l}\text { Bawa } \\
\text { h Baja }\end{array}$ \\
\hline & $\begin{array}{l}\text { Jenis } \\
\text { Beban }\end{array}$ & $\underset{n}{\text { Mome }}$ & Ftc & Fts & Fbs \\
\hline & & $(\mathrm{kNm})$ & $\begin{array}{c}\mathrm{MPa} \\
)\end{array}$ & $(\mathrm{MPa})$ & $(\mathrm{MPa})$ \\
\hline 1 & $\begin{array}{l}\text { Berat } \\
\text { sendiri } \\
(\mathrm{MS})\end{array}$ & 490,6 & 2,373 & 8,372 & $\begin{array}{c}38,92 \\
9\end{array}$ \\
\hline 2 & $\begin{array}{l}\text { Beban } \\
\text { mati } \\
\text { tambaha } \\
\mathrm{n}(\mathrm{MA})\end{array}$ & 188,3 & 0,911 & 3,213 & $\begin{array}{c}14,94 \\
1\end{array}$ \\
\hline 3 & $\begin{array}{l}\text { Beban } \\
\text { lajur "D" } \\
\text { (TD) }\end{array}$ & 1100,2 & 5,37 & $\begin{array}{c}18,94 \\
5\end{array}$ & $\begin{array}{c}88,09 \\
3\end{array}$ \\
\hline 4 & $\begin{array}{l}\text { Gaya } \\
\text { rem } \\
(\mathrm{TB})\end{array}$ & 56 & 0,271 & 0,957 & 4,448 \\
\hline 5 & $\begin{array}{l}\text { Beban } \\
\text { angin } \\
(\mathrm{EW})\end{array}$ & 50,4 & 0,244 & 0,86 & 3,999 \\
\hline 6 & $\begin{array}{l}\text { Beban } \\
\text { gempa } \\
\text { (EQ) }\end{array}$ & 67,89 & 0,328 & 1,159 & 5,387 \\
\hline
\end{tabular}
komposit sebagai berikut :

Tabel 4.16 Tegangan terhadap girder komposit

\section{a. Kombinasi 1}

Tegangan ijin beton : $100 \% . \mathrm{Fc}=11 \mathrm{MPa}$ 
Tegangan ijin baja $: 100 \% . F s=160 \mathrm{Mpa}$

Tabel 4.17 Tegangan terhadap girder komposit kombinasi-1

\begin{tabular}{|c|c|c|c|c|}
\hline & $\begin{array}{l}\text { Tegangan yang } \\
\text { terjadi pada sisi }\end{array}$ & $\begin{array}{l}\text { Atas } \\
\text { Beton }\end{array}$ & $\begin{array}{l}\text { Atas } \\
\text { Baja }\end{array}$ & $\begin{array}{c}\text { Bawah } \\
\text { Baja }\end{array}$ \\
\hline \multirow[t]{2}{*}{ No } & $\begin{array}{r}\text { Jenis } \\
\text { Beban }\end{array}$ & $\mathrm{ftc}$ & $\mathrm{fts}$ & $\mathrm{fbs}$ \\
\hline & & (MPa) & $(\mathrm{MPa})$ & (MPa) \\
\hline 1 & $\begin{array}{l}\text { Berat sendiri } \\
\text { (MS) }\end{array}$ & 2,373 & 8,372 & 38,929 \\
\hline 2 & $\begin{array}{l}\text { Beban mati } \\
\text { tambahan } \\
\text { (MA) }\end{array}$ & 0,911 & 3,213 & 14,941 \\
\hline 3 & $\begin{array}{l}\text { Beban lajur } \\
\text { "D" (TD) }\end{array}$ & 5,73 & 18,945 & 88,093 \\
\hline 4 & $\begin{array}{l}\text { Gaya rem } \\
\text { (TB) }\end{array}$ & & & \\
\hline 5 & $\begin{array}{l}\text { Beban angin } \\
(\mathrm{EW})\end{array}$ & & & \\
\hline \multirow[t]{4}{*}{6} & $\begin{array}{l}\text { Beban } \\
\text { gempa (EQ) }\end{array}$ & & & \\
\hline & Total tegangan $=$ & 8,654 & 30,53 & 141,96 \\
\hline & & $\begin{array}{l}<100 \% \\
. \mathrm{Fc}\end{array}$ & & $\begin{array}{l}<100 \% \\
\text {. Fs }\end{array}$ \\
\hline & & Aman (C & & $\operatorname{nan}(\mathrm{OK})$ \\
\hline
\end{tabular}

\section{b. Kombinasi-2}

Tegangan ijin beton : $125 \%$. Fc $=14 \mathrm{MPa}$

Tegangan ijin baja $: 125 \% . F s=200 \mathrm{MPa}$

Tabel 4.18 Tegangan terhadap girder komposit kombinasi-2

\begin{tabular}{|c|c|c|c|c|}
\hline \multirow[t]{4}{*}{ No } & Tegangan & \multirow{3}{*}{$\begin{array}{l}\text { Atas } \\
\text { Beton }\end{array}$} & \multirow{3}{*}{$\begin{array}{l}\text { Atas } \\
\text { Baja }\end{array}$} & \multirow{3}{*}{$\begin{array}{l}\text { Bawah } \\
\text { Baja }\end{array}$} \\
\hline & yang terjadi & & & \\
\hline & pada sisi & & & \\
\hline & Jenis Beban & $\begin{array}{c}\mathrm{ftc} \\
(\mathrm{MPa})\end{array}$ & $\begin{array}{c}\mathrm{fts} \\
(\mathrm{MPa})\end{array}$ & $\begin{array}{c}\text { fbs } \\
(\mathrm{MPa})\end{array}$ \\
\hline 1 & $\begin{array}{l}\text { Berat sendiri } \\
\text { (MS) }\end{array}$ & 2,373 & 8,372 & 38,929 \\
\hline 2 & $\begin{array}{l}\text { Beban mati } \\
\text { tambahan } \\
\text { (MA) }\end{array}$ & 0,911 & 3,213 & 14,941 \\
\hline 3 & $\begin{array}{l}\text { Beban lajur } \\
\text { "D" (TD) }\end{array}$ & 5,73 & 18,945 & 88,093 \\
\hline 4 & $\begin{array}{ll}\text { Gaya } & \text { rem } \\
\text { (TB) } & \\
\end{array}$ & & & \\
\hline 5 & $\begin{array}{l}\text { Beban angin } \\
\text { (EW) }\end{array}$ & & & \\
\hline 6 & $\begin{array}{l}\text { Beban gempa } \\
\text { (EQ) }\end{array}$ & & & \\
\hline & Total tegangan $=$ & 10,894 & 30,53 & 141,963 \\
\hline & & $\begin{array}{l}<125 \% \\
. \mathrm{Fc}\end{array}$ & & $\begin{array}{l}<125 \% . \\
\text { Fs }\end{array}$ \\
\hline & & $\operatorname{Aman}(\mathrm{Ok})$ & & an $(\mathrm{Ok})$ \\
\hline
\end{tabular}

$\mathrm{MPa}$

\section{c. Kombinasi 3}

Tegangan ijin beton : $125 \%$. Fc $=11 \mathrm{MPa}$ Tegangan ijin baja : $125 \% . F s=200 \mathrm{MPa}$

Tabel 4.19 Tegangan terhadap girder komposit kombinasi-3

\begin{tabular}{|c|c|c|c|c|}
\hline \multirow[t]{4}{*}{ No } & Tegangan yang & \multirow{3}{*}{$\begin{array}{l}\text { Atas } \\
\text { Beton }\end{array}$} & \multirow{3}{*}{$\begin{array}{l}\text { Atas } \\
\text { Baja }\end{array}$} & \multirow{3}{*}{$\begin{array}{l}\text { Bawah } \\
\text { Baja }\end{array}$} \\
\hline & terjadi $\quad$ pada & & & \\
\hline & sisi & & & \\
\hline & Jenis Beban & $\begin{array}{c}\mathrm{ftc} \\
(\mathrm{MPa})\end{array}$ & $\begin{array}{c}\mathrm{fts} \\
(\mathrm{MPa})\end{array}$ & $\begin{array}{c}\mathrm{fbs} \\
(\mathrm{MPa})\end{array}$ \\
\hline 1 & $\begin{array}{ll}\text { Berat } & \text { sendiri } \\
(\mathrm{MS}) & \end{array}$ & 2,373 & 8,372 & 38,929 \\
\hline 2 & $\begin{array}{l}\text { Beban mati } \\
\text { tambahan } \\
\text { (MA) }\end{array}$ & 0,911 & 3,213 & 14,941 \\
\hline 3 & $\begin{array}{l}\text { Beban lajur } \\
\text { "D" (TD) }\end{array}$ & 5,73 & 18,945 & 88,093 \\
\hline 4 & Gaya rem (TB) & & & \\
\hline 5 & $\begin{array}{l}\text { Beban angin } \\
(\mathrm{EW})\end{array}$ & 0,243 & 0,86 & 3,999 \\
\hline \multirow[t]{4}{*}{6} & $\begin{array}{l}\text { Beban gempa } \\
\text { (EQ) }\end{array}$ & & & \\
\hline & \multirow[t]{3}{*}{ Total tegangan $=$} & 8,898 & 31,39 & 145,96 \\
\hline & & $\begin{array}{l}<\quad 125 \\
\% . \mathrm{Fc}\end{array}$ & & $\begin{array}{l}<125 \% \\
\text {. Fs }\end{array}$ \\
\hline & & Aman(C & & $\operatorname{Aman}(\mathrm{Ok})$ \\
\hline
\end{tabular}

\section{d. Kombinasi-4}

Untuk kombinasi-4 beban yang bekerja dihitung seluruhnya untuk memperoleh perencanaan yang aman dan kuat dalam kondisi yang berbahaya (kombinasi beban seluruhnya), hanya beban gempa saja yang tidak diperhitungkan.

Tegangan ijin beton : $140 \% . \mathrm{Fc}=16 \mathrm{MPa}$ Tegangan ijin baja $: 140 \% . F s=224 \mathrm{MPa}$

Tabel 4.20. Tegangan terhadap girder komposit kombinasi-4

\begin{tabular}{|c|c|c|c|c|}
\hline \multirow[t]{3}{*}{ No } & \multirow{2}{*}{$\begin{array}{l}\text { Tegangan } \\
\text { yang terjadi } \\
\text { pada sisi }\end{array}$} & \multirow{2}{*}{$\begin{array}{l}\text { Atas } \\
\text { Beton }\end{array}$} & \multirow{2}{*}{$\begin{array}{l}\text { Atas } \\
\text { Baja }\end{array}$} & \multirow{2}{*}{$\begin{array}{l}\text { Bawah } \\
\text { Baja }\end{array}$} \\
\hline & & & & \\
\hline & Jenis Beban & $\begin{array}{c}\mathrm{ftc} \\
(\mathrm{MPa})\end{array}$ & $\begin{array}{c}\mathrm{fts} \\
(\mathrm{MPa})\end{array}$ & $\begin{array}{c}\mathrm{fbs} \\
(\mathrm{MPa})\end{array}$ \\
\hline 1 & $\begin{array}{l}\text { Berat sendiri } \\
\text { (MS) }\end{array}$ & 2,373 & 8,372 & 38,929 \\
\hline 2 & $\begin{array}{l}\text { Beban mati } \\
\text { tambahan } \\
\text { (MA) }\end{array}$ & 0,911 & 3,213 & 14,941 \\
\hline 3 & $\begin{array}{l}\text { Beban lajur } \\
\text { "D" (TD) }\end{array}$ & 5,73 & 18,945 & 88,093 \\
\hline 4 & $\begin{array}{l}\text { Gaya } \quad \text { rem } \\
\text { (TB) }\end{array}$ & 0,271 & 0,956 & 4,447 \\
\hline
\end{tabular}




\begin{tabular}{clccc}
\hline 5 & $\begin{array}{l}\text { Beban angin } \\
(\text { EW) }\end{array}$ & 0,243 & 0,86 & 3,999 \\
6 & $\begin{array}{l}\text { Beban gempa } \\
(\text { EQ) }\end{array}$ \\
Total tegangan $=$ & 9,169 & 32,347 & 150,409 \\
& $<140$ & $<140 \%$. \\
& & & \\
& & Aman $(\mathrm{Ok})$ & Fman $(\mathrm{Ok})$ \\
\hline
\end{tabular}

\section{e. Kombinasi-5}

Sedangkan kombinasi-5 beban kerja dihitung semua untuk mengetahui beban maksimum yang bekerja seluruhnya.

Tegangan ijin beton : $150 \% . \mathrm{Fc}=17 \mathrm{MPa}$

Tegangan ijin baja $: 150 \%$. Fs $=240 \mathrm{MPa}$

Tabel 4.21 Tegangan terhadap girder komposit kombinasi-5

\begin{tabular}{|c|c|c|c|c|}
\hline \multirow[t]{2}{*}{$\mathrm{No}$} & $\begin{array}{l}\text { Tegangan } \\
\text { yang terjadi } \\
\text { pada sisi }\end{array}$ & $\begin{array}{l}\text { Atas } \\
\text { Beton }\end{array}$ & $\begin{array}{l}\text { Atas } \\
\text { Baja }\end{array}$ & $\begin{array}{l}\text { Bawah } \\
\text { Baja }\end{array}$ \\
\hline & Jenis Beban & $\begin{array}{c}\mathrm{ftc} \\
(\mathrm{MPa})\end{array}$ & $\begin{array}{c}\mathrm{fts} \\
(\mathrm{MPa})\end{array}$ & $\begin{array}{c}\mathrm{fbs} \\
(\mathrm{MPa})\end{array}$ \\
\hline 1 & $\begin{array}{l}\text { Berat sendiri } \\
\text { (MS) }\end{array}$ & 2,373 & 8,372 & 38,929 \\
\hline 2 & $\begin{array}{l}\text { Beban mati } \\
\text { tambahan } \\
\text { (MA) }\end{array}$ & 0,911 & 3,213 & 14,941 \\
\hline 3 & $\begin{array}{l}\text { Beban lajur } \\
\text { "D" (TD) }\end{array}$ & 5,73 & 18,945 & 88,093 \\
\hline 4 & $\begin{array}{ll}\text { Gaya } & \text { rem } \\
\text { (TB) } & \end{array}$ & 0,271 & 0,956 & 4,447 \\
\hline 5 & $\begin{array}{l}\text { Beban angin } \\
(\mathrm{EW})\end{array}$ & 0,243 & 0,86 & 3,999 \\
\hline 6 & $\begin{array}{l}\text { Beban gempa } \\
\text { (EQ) }\end{array}$ & 0,328 & 1,158 & 5,386 \\
\hline & Total tegangan $=$ & 12,076 & 42,601 & 183,568 \\
\hline & & $\begin{array}{l}<150 \% \\
. \mathrm{Fc}\end{array}$ & & $\begin{array}{l}<150 \% . \\
\text { Fs }\end{array}$ \\
\hline & & Aman $(C$ & & Aman (Ok) \\
\hline
\end{tabular}

\section{g. Perhitungan Shear Connector}

Perhitungan shear connector yang direncanakan menggunakan beban terbesar dari gaya geser maksimum yang diperoleh, karena untuk memperoleh struktur yang aman dan kuat. Dalam hal digunakan jenis penghubung geser bentuk paku (connector stud), SNI 03- 1729-2002 dan AISC 2010 menetapkan, kekuatan nominal penghubung geser jenis konektor stud dengan panjang $4 \mathrm{x}$ diameter (Lc > 4D) yang ditanam dalam beton masif, adalah salah stu dari persamaan berikut.

$\mathrm{Q}_{\mathrm{n}}=0,5 . \mathrm{A} \cdot \sqrt{\mathrm{fc} \cdot \text { Ec }}$ atau $\mathrm{Qn}=\mathrm{A}$. fu., dipakai connector stud produk ANTEC. Hasil perhitungan
Jumlah connector stud seluruh bentang $=2$. $(50+$ 26) buah $=152$ buah

Gaya geser memanjang rencana per satuan panjang (RSNI T-03-2005), VL*, harus memenuhi:

$\mathrm{V}_{\mathrm{L}} \leq \phi \mathrm{V}_{\mathrm{LS}}$

$\mathrm{V}_{\mathrm{LS}}=0,55 . \mathrm{n} \cdot \mathrm{Qn}$

$\mathrm{V}_{\mathrm{L}}=361,04 \mathrm{kN}$

$\mathrm{V}_{\mathrm{LS}}=0,55.60 .74355,2=2453721,6 \mathrm{~N}$

$$
=2453,721 \mathrm{kN}
$$

$\phi \mathrm{V}_{\mathrm{LS}}=0,75.2453,721=1840,291 \mathrm{kN}>\mathrm{V}_{\mathrm{L}}=$ $361,04 \mathrm{kN}$

Dimana, $\phi=$ Faktor reduksi kekuatan $=0,85(\mathrm{SNI}$ 03-1729-2002, AISC 2010)

$$
\begin{aligned}
& =0,75(\text { RSNI T-03-2005) } \\
\mathrm{n} & =\text { jumlah penghubung geser }
\end{aligned}
$$

\section{h. Perencanaan Sambungan Girder}

Bentang $40 \mathrm{~m}$ terdapat pilar di tengah, bentang antar pilar $20 \mathrm{~m}$ dari jembatan ini dibagi menjadi 2 segmen, panjang profil yang digunakan $10 \mathrm{~m}$ maka dari itu diperlukan sambungan.

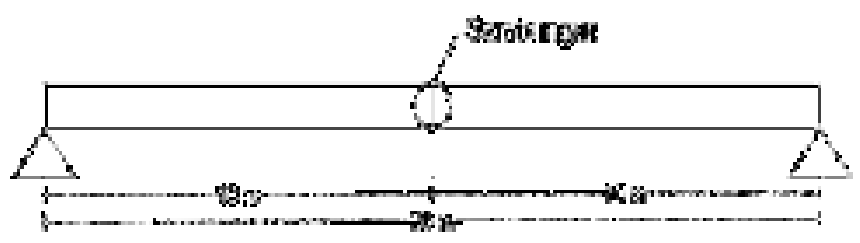

Gambar 4.5 Perencanaan sambungan Sumber : RSNI T-03-2005 Perencanaan struktur baja untuk jembatan

\section{i. Pembebanan Untuk Pemasangan Baut}

Beban yang digunakan berasal dari perhitungan beban sebelumnya dengan mengambil nilai momen maksimum, dan gaya geser maksimum sebagai berikut :

Vumax $=419,66 \mathrm{kN}$

$\operatorname{Mmax}=1 / 4$. Vumax. $\mathrm{L}$

$$
=0,25.419,66 \cdot 20=2098,29 \mathrm{kNm}
$$

Pembagian beban momen

I badan $=1 / 12 \cdot b \cdot h^{3}$

$$
=1 / 12 \cdot 1,6 \cdot 77^{3}=60871,06 \mathrm{~cm}^{4}
$$

Iprofil $\quad=339000 \mathrm{~cm}^{4}$

Mu badan $=\frac{\text { Ibadan }}{\text { Iprofil }}$ Mmax

$\frac{60871,06}{339000} 2098,29$ 


$$
=376,77 \mathrm{kNm}
$$

Mu sayap

$$
\begin{aligned}
& =\text { Mmax }- \text { Mu badan } \\
& =2098,29-376,77=1722 \mathrm{kNm}
\end{aligned}
$$

\section{j. Perencanaan Sambungan Sayap}

1. Tegangan izin Baja BJ-410

Baut, $\quad f_{u}^{b}=825 \mathrm{Mpa}$

Pelat, $\quad f y=250 \mathrm{Mpa}$

$\mathrm{fu}=410$ Mpa Jumlah bidang geser $(\mathrm{n})=2$

2. Rencana baut

Memakai baut $\varnothing=20 \mathrm{~mm}$

Diameter lobang

$\mathrm{d}_{1}=20 \mathrm{~mm}+2 \mathrm{~mm}=22 \mathrm{~mm}$

3. Tinjau terhadap kekuatan geser

$\mathrm{Rn}=\mathrm{m} \cdot \mathrm{r}_{1} \cdot f_{u}^{b} \cdot \mathrm{Ab}$

Dimana

$\mathrm{m}=2$ bidang geser

$\mathrm{r}_{1}=0,4$ untuk bidang geser baut berulir

$\mathrm{Ab}=1 / 4 . \pi . \emptyset^{2}$

$$
=0,25 \cdot 3,14 \cdot 20^{2}=314 \mathrm{~mm}^{2}
$$

Maka

$\mathrm{Rn}=2.0,4.825 \cdot 314=207240 \mathrm{~N}$

$=207,24 \mathrm{kN} \phi \mathrm{Rn}=0,75.207,24$

$=155,43 \mathrm{kN}$

4. Tinjau terhadap kekuatan tumpu,tebal pelat terkecil

$\mathrm{tp}=30 \mathrm{~mm} \mathrm{Rn}=\mathrm{n}$. $\mathrm{d}_{\mathrm{b}} \cdot \mathrm{tp}$. fu Dimana

$\mathrm{n}=2,4$ berlaku untuk semua jenis lobang

baut $\emptyset=20 \mathrm{~mm}$, tp $=25 \mathrm{~mm}$ Maka

$\mathrm{Rn}=2,4.20 \cdot 30.410=590400 \mathrm{~N}$

$$
=590,4 \mathrm{kN}
$$

$\phi \mathrm{Rn}=0,75.590,4=442800 \mathrm{~N}=442,8 \mathrm{kN}$

5. Jumlah baut Yang menentukan adalah akibat geser, maka jumlah baut Gaya kopel sayap $\mathrm{Tu}=\frac{\text { Mu sayap }}{\mathrm{d}}=\frac{1722}{0,77}=2235,74 \mathrm{kN}$

Jumlah baut yang diperlukan

$$
\mathrm{n}=\frac{\mathrm{Tu}}{\emptyset \mathrm{Rn}}=\frac{2235,74}{155,43}=14,39 \mathrm{buah},
$$

baut yang digunakan 16 buah

6. Susunan baut Sambungan pelat dengan pengikat baut

Keterangan : Tata letak Baut $3 \mathrm{~d} \leq \mathrm{S} \leq 15 \mathrm{tp} 3$.

$20 \leq \mathrm{S} \leq 15.3060 \leq \mathrm{S} \leq 450$ diambil jarak 60 $\mathrm{mm}$

$1,5 \mathrm{~d} \leq \mathrm{S} 1 \leq(4 \mathrm{tp}+100 \mathrm{~mm})$ atau $200 \mathrm{~mm}$ $1,5.20 \leq \mathrm{S} 1 \leq(4.3+100 \mathrm{~mm})$ atau $200 \mathrm{~mm}$

$30 \leq \mathrm{S} 1 \leq 220$ Diambil jarak $50 \mathrm{~mm}$

Jumlah daya dukung 16 buah baut :

$\mathrm{Rn}=16 . \varnothing \mathrm{Rn}$
$=16.155,43=2486,88 \mathrm{kN}>2235,74 \mathrm{kN}$

(Ok) memenuhi

7. Pelat, Cek luas penampng minimum luas

penampng bruto :

$A_{b}=30.300=9000 \mathrm{~mm}^{2}$ Syarat luas

penampng minimum $: \mathrm{A}_{\min }=85 \% \cdot \mathrm{A}_{\mathrm{b}}=0,85$.

$9000=7650 \mathrm{~mm}^{2}$

Luas penampang netto: $A_{\text {netto }}=A_{b}-2 \cdot d_{1} \cdot t_{p}$

$=9000-2.22 .30=7680 \mathrm{~mm}^{2}$

$\mathrm{x}=30 / 2=15 \mathrm{~mm}$

$\mathrm{L}=4 \mathrm{~S}=4.60=240 \mathrm{~mm}$

Koefisien reduksi :

$\mathrm{U}=1-\mathrm{x} / \mathrm{L}$

$=1-15 / 240=1-0,06=0,94>0,9$

$\mathrm{U}=1,0$ (SNI 03-1729-2002,Psl. 10.2.5)

Maka :

$\mathrm{A}_{\mathrm{e}}=\mathrm{A}_{\text {netto }}=7680 \mathrm{~mm}^{2}$

8. Cek daya dukung pelat pada daerah sambungan

$\mathrm{Ru}=\phi \mathrm{A}_{\text {netto }} . \mathrm{fu}$

$=0,75.7680 .410=2361600 \mathrm{~N}=2361,6 \mathrm{kN}$

$=2361,6>2235,74(\mathrm{Ok})$

9. Cek terhadap geser balok Kondisi geser blok diperiksa untuk pelat sambungan dengan nilai tebal terkecl, $\mathrm{tp}=30 \mathrm{~mm}$. Daerah geser balok pada sambungan :

Luas Anv $=2 .(470-7,5.20) .30=19200$

$\mathrm{mm}^{2}$, Ant $=2 .(50-0,5 \cdot 20) .30=2400 \mathrm{~mm}^{2}$

$0,6 \cdot f u \cdot A n v=0,6 \cdot 410 \cdot 19200=4723200 \mathrm{~N}$

$=4723,2 \mathrm{kN}$

fu. Ant $=410.2400=984000 \mathrm{~N}=984 \mathrm{kN}$

Karena 0,6 . fu . Anv $>$ fu . Ant, maka kondisi geser fraktur tarik leleh menentukan :

$\phi \mathrm{R}_{\mathrm{bs}}=\phi(0,6$. fu . Anv + fy . Ant $)$

$=0,75(0,6 \cdot 410 \cdot 19200+250.2400)$

$=4386150 \mathrm{~N}=4386,15 \mathrm{kN}>$ Tu sayap

$=2235,74 \mathrm{kN}(\mathrm{Ok})$

\section{k. Perencanaan Sambungan Badan}

Dengan menggunakan SNI T-03-2005 Perencanaan struktur baja untuk jembatan, seluruh baut aman untuk digunakan karena mampu manhan gaya tarik dan gaya geser, baut yang bekerja mahanan beban ultimit lebih kecil dari kuat geser sebesar 304,67 kN dan kuat tumpu sebesar $299,7 \mathrm{kN}$

\section{Sambungan Girder dan Diafragma}

Dalam memperoleh sambungan baut yang aman, dengan beban yang telah ditentukan antar sambungan girder dan diafragma. 


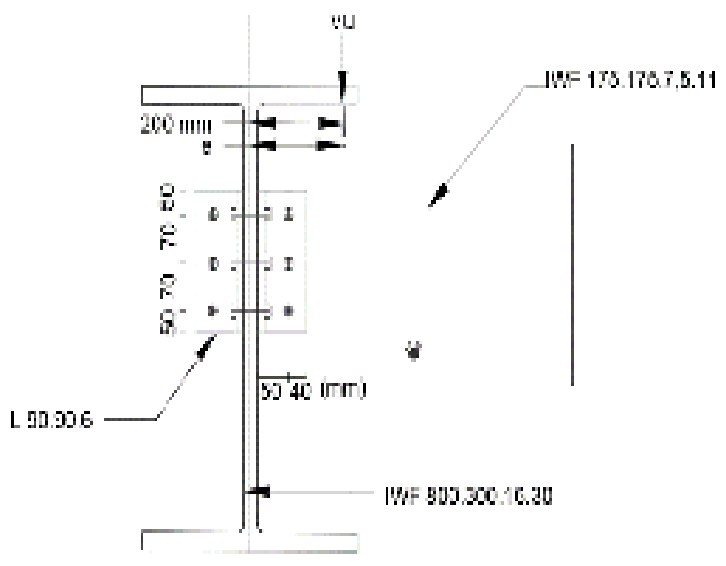

Gambar 4.6. Sambungan diafragma pengaku Sumber : RSNI T-03-2005 Perencanaan struktur baja untuk jembatan

Resultan gaya pada seluruh baut aman untuk digunakan resultan baut lebih kecil dari kekuatan nominal terfaktor baut $\langle\phi \mathrm{Rn}=16,014 \mathrm{kN}$

\section{KESIMPULAN}

Dari hasil penelitian Perhitungan Struktur Jembatan Komposit Desa Bojongloa, dapat disimpulkan beberapa kesimpulan sebagai berikut :

1. Jumlah girder pada jembatan 5 buah, sehingga jarak antar girder 1,4 m.

2. Jarak antar diafragma $4 \mathrm{~m}$.

3. Panjang bentang rencana $40 \mathrm{~m}$ dibagi dengan pilar tengah menjadi panjang masing-masing $20 \mathrm{~m}$.

4. Data hasil perencanaan dan analisis :

a. Slab trotoar

Pada perencanaan slab trotoar digunakan tulangan $\varnothing 12-150 \mathrm{~mm}$, tulangan bagi atau susut arah melintang $\varnothing 10-200 \mathrm{~mm}$. Tebal slab trotoar $30 \mathrm{~mm}$, tegangan leleh yang digunakan $240 \mathrm{MPa}$ untuk menahan beban $\mathrm{Mu}$ sebesar 36,2642 kNm, Mu = 36,2642< $\mathrm{Mn}=37,87 \mathrm{kNm}$ aman untuk digunakan.

b. Slab lantai jembatan

Pada perencanaan slab lantai jembatan, tebal slab $20 \mathrm{~cm}$, jarak tulangan terhadap sisi luar $32 \mathrm{~mm}$, sehingga lebar efektif slab $168 \mathrm{~mm}$. Momen tumpuan ultimit rencana $\mathrm{Mu}=94,475 \mathrm{kNm}<\mathrm{Mn}=102,76 \mathrm{kNm}$, dan momen lapangan tumpuan ultimit rencana $\mathrm{Mu}=73,654 \mathrm{kNm}<\mathrm{Mn}=74,18$ $\mathrm{kNm}$. Untuk tulangan lentur negatif tulangan yang digunakan $\varnothing 16-90 \mathrm{~mm}$, untuk tulangan lentur positif tulangan yang digunakan $\emptyset 16-130 \mathrm{~mm}$.

c. Girder

Pada perencanaan girder, digunakan profil baja WF 800.300.16.30 Lebar efektif slab beton $1400 \mathrm{~mm}$. Momen inersia penampang komposit 8.297.587.181,904 $\mathrm{mm}^{4}$, Momen maksimum yang diperoleh $\mathrm{M}_{\mathrm{u}} / \phi=2570,49 \mathrm{kNm}<\mathrm{M}_{\mathrm{p}}=2644,916$ $\mathrm{kNm}$ girder aman untuk digunakan.

d. Shear connector

Pada perhitungan shear connector digunakan tulangan $2 \mathrm{D} 16-170 \mathrm{~mm} 60$ buah untuk tumpuan sampai $1 / 4 \mathrm{~L}$, dan tulangan 2 D $16-340 \mathrm{~mm} 30$ buah untuk tumpuan $1 / 4$ sampai tengah bentang, dalam memikul beban rencana sebesar $V_{\text {rencana }}$ $376,9 \mathrm{kN}<1840,291 \mathrm{kN}$ aman terhadap geser.

e. Diafragma

Diafragma yang digunakan profil IWF 175.175.7,5.11 jarak antar diafragma dalam perencanaan yang digunakn 4000 $\mathrm{mm}$. Jarak antara girder $1.400 \mathrm{~mm}$, beban maksimum yang bekerja untuk diafragma adalah $\mathrm{M}_{\max } 0,12 \mathrm{kNm}<\mathrm{M}_{\mathrm{p}}=75,51 \mathrm{kNm}$ diafragma aman untuk digunakan.

f. Sambungan

Sambungan baut yang digunakan $\emptyset 10 \mathrm{~mm}$ untuk sambungan diafragma dengan girder, untuk girder dengan girder menggunakan $\emptyset 20 \mathrm{~mm}$. Untuk sambungan diafragma dengan girder menggunakan profil L90.90.6 banyak baut 3 buah. Untuk sambungan girder dengan girder menggunaka pelat penyambung 700.400 .18 menggunakan 12 buah baut untuk bagian badan, dan16 buah untuk bagian sayap profil.

\section{DAFTAR PUSTAKA}

RSNI T-02-2005 Perencanaan Struktur Rangka Baja

RSNI T-12-2004 Perencanaan struktur beton untuk jembatan

RSNI T-02-2005 Pembebanan untuk jembatan

SNI 03 - 1729 - 2002 Beton

SNI 03 - 1729 - 2002 Baja

Setiawan Agus,"Perencanaan Struktur Baja Dengan Metode LRFD (Berdasarkan SNI 03- 1729-2002)", Penerbit AIRLANGGA, Jakarta, 2008.

Charles G. Salmon, Jhon E. Johnson,"STRUKTUR BAJA, Design dan Perilaku", Jilid 2, Penerbit AIRLANGGA, Jakarta, 1996.

Gunawan, Rudi," Tabel profil baja", Penerbit KANISIUS (ANGGOTA IKAPI), Yogyakarta. 
http://www.ilmutekniksipilindonesia.com/2016/08 /dasar-dasar-perencanaan-jembatan.htm (Diakses Pukul 11:00, Sabtu, 2-Februari2019)

https://ratnamercusuar.wordpress.com/2017/07/09/ baja-dan-besi/ (Diakses Pukul 09:00, Sabtu, 2-Februari-2019)

https:/tekniksipil411.wordpress.com/2016/04/17/firstblog-post/ (Diakses Pukul 10:00 Senin, 4Februari-2019)

https://ratnamercusuar.wordpress.com/2017/07/09/bajadan-besi/ (Diakses Pukul 08:00, Senin, 4Februari-2019)

http://www.hdesignideas.com/2012/06/memahamimutu-beton-fc-mpa-dan-mutu.html (Diakses Pukul 18:00, Selasa, 5-Februari-2019)

https://id.scribd.com/doc/81805676/JENISJEMBATAN (Diakses Pukul 21:00, Rabu, 4Februari-2019)

http:/ilmusipil21.blogspot.com/2016/02/jembatanbeton-bertulang-definisi.html (Diakses Pukul 19:00, Jumat, 6-Februari-2019)

http://ali10wafa.blogspot.com/p/plat-lantaiatap-betonplat-lantai-yang.html(Diakses Pukul 9:00, Selasa, 26-Februari-2019)

http://www.datajembatan.com (Diakses Pukul 13:00, Sabtu, 2-Februari-2019)

https://docplayer.info/51369180-Plate-girder-apengertian-pelat-girder.html (Diakses Pukul 15:00, Selasa, 5-Maret-2019)

http://www.shantywp.co.id/gallery/swasta/Jalan-Jembatan-and-Tower (Diakses Pukul 18:00 Kamis, 5-Maret 2019)

https://www.kompasiana.com/gapeysandy/567c0d826d7e61fd13cc5659/inovasijembatan-ortotropik-lebih-cepat-dan-lebihringan?page=all (Diakses Pukul 11:00, Sabtu, 9Maret-2019)

https://www.radarbangka.co.id/berita/detail/belitong/43 963/jembatan-minapolitan-ternyata-sudahpho.html (Diakses Pukul 10:00, Sabtu, 9-Maret2019)

http://www.newkidjoy.com/2011/03/perencanaanstruktur-beton-pelat-lantai.html (Diakses Pukul 09:00, Selasa, 12-Maret-2019) 